\title{
Meningothelial Hamartoma
}

National Cancer Institute

\section{Source}

National Cancer Institute. Meningothelial Hamartoma. NCI Thesaurus. Code C121682.

A hamartoma characterized by the presence of collections of non-neoplastic arachnoidal cells. 